\title{
Pengembangan Modul Biologi Problem Based Learning Untuk Meningkatkan Kemampuan Berpikir Kritis Peserta Didik SMA
}

\author{
Ike Selviani $^{1}$ \\ ${ }^{1}$ UIN Raden Intan Lampung, Bandar Lampung, Lampung, Indonesia \\ Coressponding Author. E-mail: \\ 1selvianiclouds@gmail.com
}

Received: 16 Juli 2019

Accepted: 28 Juli 2019

Online Published: 30 Juli 2019

\begin{abstract}
Abstrak
Penelitian ini bertujuan mengetahui: (1) kelayakan modul biologi problem based learning (PBL) tentang materi sistem pernapasan, (2) efektivitas modul biologi PBL pada materi sistem pernapasan terhadap kemampuan berpikir kritis, dan (3) perbedaan prestasi peserta didik yang menggunakan modul biologi PBL dengan peserta didik yang hanya belajar menggunakan model PBL dan tanpa modul biologi PBL. Jenis penelitian ini research and development (R\&D). Populasi penelitian kelas XI MIPA 1 berjumlah 34 peserta didik sebagai kelas eksperimen dan XI MIPA 2 berjumlah 34 peserta didiksebagai kelas kontrol di SMA N 1 Bandar Lampung. Pengujian produk menggunakan desain kuasi eksperimen yaitu nonequivalent control group pretest posttest design. Teknik pengumpulan data menggunakan teknik tes dan nontes. Teknik analisis menggunakan uji U Mann Withney. Hasil penelitian menunjukkan: (1) modul biologi PBL materi sistem pernapasan yang dikembangkan memenuhi syarat kelayakan dari aspek substansi, konstruksi dan bahasa, (2) modul biologi PBL yang dikembangkan efektif dalam meningkatkan kemampuan berpikir kritis peserta didik SMA, dan (3) terdapat perbedaan prestasi belajar yang signifikan antara peserta didik yang menggunakan modul biologi PBL dengan yang menggunakan model PBL tanpa modul dilihat dari tingkat ketercapaian proses belajar peserta didik yang menggunakan modul dengan langkah PBL secara mandiri lebih tinggi dibanding dengan yang dibimbing oleh guru tanpa modul.
\end{abstract}

Kata Kunci: Problem Based Learning, Berpikir Kritis, Pengembangan Modul.

\begin{abstract}
This study aims to: (1) determine the feasibility of biological problem based learning (PBL) modules in material respiratory system, (2) assess the effectiveness of biological PBL modules in respiratory system materials for critical thinking skills, and (3) find out the difference achievements of learners who use biology PBL modules and students who are just learning to use a model PBL model without biological problem based learning modules. This research used $\mathrm{R} \& \mathrm{D}$ (Research and Development). This research consists of two classes, the experimental class with 34 students of class XI SMAN 1 Bandar Lampung and the control class with 34 students of class XI SMAN 1 Bandar Lampung. The product testing used in this research was quasy experiment design; it was nonequivalent control group pretest posttest design. The data were collected using tests and non-test. the analysis was done through Mann Withney U-Test. The result of the analysis show that: (1) the developing of biological PBL modules in material respiratory system fill of condition in material, contruction, and language/communication aspects, (2) the developing of biological PBL module is effective to improve the students ability in critical thinking of senior-bigh-school, and (3) There are significant differences in academic achievement between students who use the module of biological PBL and use the PBL models without module seen from the level of achievement in learning process of learners who use the module to move independently PBL bigher than guided by teacher without the module.
\end{abstract}

Keywords : Problem Based Learning, Critical Thinking, Development Module

How to cite this article :

Selviani, I. (2019). Pengembangan Modul Biologi Problem Based Learning Untuk Meningkatkan Kemampuan Berpikir Kritis Peserta Didik SMA. IJIS Edu : Indonesian Journal of Integrated Science Education, 1(2). doi:http://dx.doi.org/10.29300/ijisedu.v1i2.2032 


\section{PENDAHULUAN}

Media pembelajaran bermacam-macam yang biasa digunakan dalam pembelajaran bermacammacam seperti media audio, visual, dan audiovisual. Media audio seperti piringan hitam, CD (compact disk), dan radio. Media visual seperti printed material (buku, modul, majalah, koran), lembar kerja siswa, gambar (chart) dan lainnya. Media audio-visual seperti televisi, film, dan lainnya. Dalam penelitian ini, peneliti memutuskan untuk mengembangkan media pembelajaran dalam bentuk cetak yaitu modul.

Sesuai dengan pengertian modul menurut Supriyatno (2006, p.1) bahwa modul dapat diartikan sebagai materi pelajaran yang disusun dan disajikan secara tertulis sedemikian rupa sehingga pembacanya diharapkan dapat menyerap sendiri materi tersebut. Modul memiliki karakteristik tersendiri agar dapat mencapai suatu tujuan pembelajaran yaitu (1) self instructional, (2) pengakuan atas perbedaan individual, (3) memuat rumusan tujuan pembelajaran secara spesifik dan eksplisit, (4) adanya asiasi, struktur, dan urutan pengetahuan, (5) penggunaan berbagai macam media pembelajaran, (6) partisipasi aktif peseta didik dalam pembelajaran, (7) adanya reinforcement langsung terhadap respon peserta didik, dan (8) adanya evaluasi kontinyu dan berkali-kali terhadap penguasaan peserta didik atas hasil belajarnya (Vembriarto, 1974, p.42)

Berdasarkan hasil observasi dan ditemukan permasalahan yang berkaitan dengan guru, peserta didik, serta sarana dan prasarana maka semakin meyakinkan peneliti untuk membuat suatu penelitian yang membantu mengurangi permasalahan sekolah yaitu mengembangkan modul biologi yang dipadukan dengan model pembelajaran dan materi pembelajaran yang sesuai sehingga dapat membantu meningkatkan kemampuan berpikir peserta didik. Setelah dilakukan peninjauan maka dipilihlah model problem based learning (PBL) yang memiliki karakteristik yang tepat dengan tujuan peneliti yaitu meningkatkan kemampuan berpikir kritis sesuai dengan pernyataan Yarid \& Ariswan (2016, p.26) bahwa dalam sintaks PBL terdapat aktivitas yang mengharuskan peserta didik melakukan pengamatan dan pengumpul data, sehingga perlu menerapkan metode pembelajaran yang memfasilitasi aktivitas tersebut.

Pemilihan materi yang tepat dalam suatu pembelajaran menggunakan model dan media pembelajaran dapat membantu peserta didik mengembangkan pengetahuan dan kemampuan berpikir yang dimiliki oleh peserta didik terutama dalam meningkatkan kemampuan berpikir kritis.
Berpikir kritis merupakan bagian terpenting dan sangat hangat dibicarakan oleh para ilmuan baik dari bidang pendidikan maupun bidang umum. Facione (2011, p.5), Ricketts \& Rudd (2005, p.33) dan Haghpharast, Hanum \& Noorhidawati (2013, p.528), menyatakan berpikir kritis merupakan suatu kegiatan seperti interpretasi, analisis, menyimpulkan, evaluasi, menjelaskan dan pengaturan diri (self efficacy). Tujuan penelitian tentang pengembangan modul biologi PBL materi sistem pernapasan untuk meningkatkan kemampuan berpikir krtitis adalah (1)mengembangkan modul biologi problem based learning (PBL) pada materi sistem pernapasan, (2)mengetahui efektivitas modul biologi problem based learning (PBL) pada materi sistem pernapasan terhadap kemampuan berpikir kritis dan (3) mengetahui perbedaan prestasi peserta didik yang menggunakan modul biologi problem based learning (PBL) dengan peserta didik yang hanya belajar menggunakan model problem based learning tanpa modul biologi problem based learning (PBL).

\section{METODE PENELITIAN}

Penelitian ini menggunakan jenis penelitian R\&D (Research and Development). Penelitian ini dilakukan untuk mengembangkan produk berupa modul biologi Problem Based Learning (PBL) dalam bentuk media cetak dan dilakukan sampai pada tahap validasi. Penelitian ini menggunakan desain kuasi eksperimen yaitu nonequivalent control group pretest posttest design. Dilaksanakan pada bulan Maret tahun 2016 sampai dengan bulan Mei tahun 2016, di SMA N 1 Bandar Lampung Provinsi Lampung dengan jumlah peserta didik secara keseluruhan 68 peserta didik. Subjek penelitian terdiri dari XI MIPA 1 berjumlah 34 peserta didik yang digunakan sebagai kelas eksperimen dan XI MIPA 2 berjumlah 34 peserta didik yang digunakan sebagai kelas kontrol. Pemilihan kelas dilakukan dengan cluster random sampling lalu dilakukan kembali pemilihan kelas dengan cara pengundian.

Prosedur pengembangan dan penelitian yang digunakan pada penelitian ini mengacu pada desain R\&D (Research and Development) yang dikembangkan oleh Thiagarajan, Semmel, \& Semmel yaitu model 4-D (four-D-model). Terdiri dari empat tahap yaitu define (pendefinisian), design (perancangan), develop (pengembangan), dan disseminate (penyebarluasan). Pengembangan produk hanya dibatasi pada tahap develop (pengembangan).

Pelaksanaan uji lapangan menggunakan desain kuasi eksperimen yaitu nonequivalent control group pretest posttest design maka dapat diketahui pada Tabel 1. 
Table 1. Desain Uji Coba

\begin{tabular}{cccc}
\hline Kelompok & $\begin{array}{c}\text { Pre } \\
\text { test }\end{array}$ & Perlakuan & $\begin{array}{c}\text { Post } \\
\text { test }\end{array}$ \\
\hline Perlakuan & O1 & X1 & O2 \\
\hline kontrol & O1 & - & O2 \\
\hline
\end{tabular}

\section{Teknik Pengumpulan Data}

Teknik pengumpulan data dilakukan dengan dua cara yaitu pemberian instrumen test dan nontest. Teknik tes, digunakan pada saat pre test dan post test dalam bentuk item uraian yang disesuaikan dengan indikator kemampuan berpikir kritis. Teknik nontes, yang digunakan dalam penelitian ini adalah kuesioner berupa rating scale model diberikan kepada tim dosen ahli, teman sejawat, guru biologi dan peserta didik gunanya untuk mengetahui respon penggunaan modul pembelajaran biologi problem based learning (PBL). Kemudian dilakukan pembakuan instrumen untuk mengetahui kevalidan dan reliabilitas soal dengan menggunakan program QUEST yang dilanjutkan dengan perhitungan keandalan item menggunakan koefisien Kappa dan indeks sensitifitas item (kualitas item yang akan digunakan pada penelitian).

Teknik Analisis Data

Penelitian ini menggunakan teknik analisis data secara kualitatif maupun kuatitaif. Analisis data kualitatif berupa kritik dan saran untuk perbaikan pengembangan modul biologi PBL oleh dosen ahli, guru, teman sejawat dan peserta didik. Sedangkan analisis data kuantitatif berupa rating scale model dengan data berupa skor dari validator dalam bentuk kategori dan berupa instrumen tes yang dianalisis menggunakan analisis statistik deskriptif dan analisis statistik inferensial.

Analisis statistik deskriptif digunakan untuk menganalisis data dengan cara mendeskripsikan data yang terkumpul. Statistik digunakan untuk menyajikan data dari hasil pengukuran variabel terikat yaitu kemampuan berpikir kritis peserta didik dalam bentuk tabel (disajikan nilai rata-rata pretes dan postes, nilai maksimal pre test dan post test, nilai minimal pre test dan post test, nilai standar deviasi serta persentase kenaikan hasil antara pre test dan post test yang dilakukan pada kelas eksperimen dan kelas kontrol. Sedangkan untuk analisis statistik inferensial menggunakan uji prasyarat terlebih dahulu untuk mengetahui apakah data yang diperoleh terdistribusi normal atau tidak normal serta data memiliki variansi yang sama atau tidak untuk selanjutnya dilakukan uji hipotesis menggunakan statistik parametrik jika terpenuhi asumsi dengan uji ANAKOVA dan jika tidak terpenuhi syarat parametrik menggunakan uji Mann Withney U-Test. Hal ini dilakukan untuk mengetahui apakah modul biologi PBL materi sistem pernapasan yang dikembangkan secara efektif dapat meningkatkan kemampuan berpikir kritis peserta didik dan memiliki perbedaaan yang signifikan antara kelas yang menggunakan modul biologi PBL dengan yang tidak menggunakan modul biologi PBL.

\section{HASIL DAN PEMBAHASAN}

Berdasarkan hasil pengembangan produk menggunakan desain Research and Development (R\&D) dengan model 4-D (Four-D) yang dikembangkan oleh Thiagarajan, Semmel, \& Semmel dalam penelitian ini hanya dibatasi sampai pada tahapan pengembangan (develop) yaitu tahap validasi produk berupa modul biologi problem based learning (PBL) materi sistem pernapasan untuk meningkatkan kemampuan berpikir kritis. Data hasil penelitian berupa hasil uji validasi produk, data hasil pre test dan post test pada kelas eksperimen dan kelas kontrol, uji prasyarat, dan uji hipotesis.

\section{Hasil Uji Validasi Produk}

Penilaian produk berupa modul biologi PBL dilakukan oleh tim dosen ahli yang menilai dari aspek substansi dan aspek konstruksi. Untuk penilaian oleh guru biologi, dan peer reviewer menilai dari aspek substansi dan aspek konstruksi serta peserta didik yang menilai dari aspek bahasa yang secara keseluruhan diksajikan pada Tabel 2.

Table 2 Penilaian Kualitas Modul Oleh Face V alidity

\begin{tabular}{llll}
\hline \multicolumn{1}{c}{ Penilaian } & $\begin{array}{c}\text { Rerata } \\
\text { skor }\end{array}$ & $\begin{array}{c}\text { Jumlah } \\
\text { Skor }\end{array}$ & Kategori \\
\hline Ahli Materi & 12 & 16 & $\begin{array}{l}\text { Cukup } \\
\text { Baik }\end{array}$ \\
\hline $\begin{array}{l}\text { Ahli } \\
\text { Pembelajaran }\end{array}$ & 45 & 52 & Baik \\
\hline
\end{tabular}

Berdasarkan hasil penilaian kualitas modul oleh ahli materi dan ahli pembelajaran dapat dilihat pada Tabel 2 yang termasuk dalam kategori baik dan dapat digunakan dalam uji lapangan. Uji kualitas modul kemudian dilanjutkan dengan penilaian kualitas modul oleh tiga orang guru biologi yang dapat dilihat pada Tabel 3 . 
Table 3. Penilaian Kualitas Modul Oleh Guru Biologi

\begin{tabular}{llll}
\hline Penilaian & $\begin{array}{c}\text { Rerata } \\
\text { skor }\end{array}$ & $\begin{array}{c}\text { Jumlah } \\
\text { Skor }\end{array}$ & Kategori \\
\hline $\begin{array}{l}\text { Aspek } \\
\text { Substansi }\end{array}$ & 15 & 16 & $\begin{array}{l}\text { Sangat } \\
\text { Baik }\end{array}$ \\
\hline Aspek & 52 & 52 & $\begin{array}{l}\text { Sangat } \\
\text { Kaik }\end{array}$ \\
\hline
\end{tabular}

Berdasarkan hasil penilaian kualitas modul oleh guru biologi dilihat dari nilai rata-rata yang diperoleh termasuk dalam kategori sangat baik dan dapat digunakan sebagai salah satu media belajar di lapangan dilihat dari aspek substansi (materi) dan aspek konstruksi (komponen model). Selain penilaian dari guru, kualitas modul juga harus dinilai oleh peer reviewer untuk mengetahui kualitas modul yang dikembangkan oleh peneliti dapat dilihat pada Tabel 4.

Table 4. Penilaian Kualitas Modul Oleh Peer Reviewer

\begin{tabular}{llll}
\hline Penilaian & $\begin{array}{c}\text { Rerata } \\
\text { skor }\end{array}$ & $\begin{array}{c}\text { Jumlah } \\
\text { Skor }\end{array}$ & Kategori \\
\hline $\begin{array}{l}\text { Aspek } \\
\text { Substansi }\end{array}$ & 14 & 16 & Baik \\
\hline $\begin{array}{l}\text { Aspek } \\
\text { Konstruksi }\end{array}$ & 48 & 52 & Baik \\
& & & \\
\hline
\end{tabular}

Berdasarkan hasil penilaian oleh lima orang peer reviewer dari aspek substansi (materi) dan aspek konstruksi (komponen modul) maka dapat dikategorikan dengan hasil yang baik dan dapat diterima. Sehingga dapat digunakan oleh peserta didik dalam uji lapangan. Selain itu uji kualitas modul juga harus dilakukan oleh peserta didik dengan tujuan untuk mengetahui modul yang digunakan sudah sesuai atau kurang sesuai dengan kemampuan peserta didik. Dapat dilihat pada Tabel 5.

Table 5. Penilaian Kualitas Modul Oleh Peserta Didik

\begin{tabular}{lccc}
\hline Penilaian & $\begin{array}{c}\text { Rerata } \\
\text { skor }\end{array}$ & $\begin{array}{c}\text { Jumlah } \\
\text { Skor }\end{array}$ & Kategori \\
\hline $\begin{array}{l}\text { Aspek } \\
\text { Bahasa }\end{array}$ & 60 & 80 & Baik \\
\hline
\end{tabular}

Berdasarkan Tabel 6 diketahui penilaian dari aspek bahasa oleh 15 orang peserta didik dapat dikategorikan baik dan modul dapat digunakan oleh peserta didik jika dilakukan penelitian lebih lanjut.

\section{Hasil Uji Kemampuan Berpikir Kritis}

Nilai rata-rata pre test dan post test pada kelas eksperimen dan kelas kontrol mengalami kenaikan yang baik, tetapi terdapat perbedaan yang cukup signifikan antara keduanya, seperti pada Tabel 6.

Table 6. Hasil Rerata Nilai Pre Test dan Post Test Kelas Eksperimen dan Kelas Kontrol

\begin{tabular}{|c|c|c|c|c|c|}
\hline \multicolumn{2}{|c|}{ Perolehan Nilai } & \multirow{2}{*}{$\begin{array}{l}\begin{array}{l}\text { Nilai } \\
\text { Rerata }\end{array} \\
32\end{array}$} & \multirow{2}{*}{$\begin{array}{c}\begin{array}{l}\text { Nilai } \\
\text { Max }\end{array} \\
50\end{array}$} & \multirow{2}{*}{$\begin{array}{l}\text { Nilai } \\
\text { Min } \\
20,8\end{array}$} & \multirow{2}{*}{$\begin{array}{r}\text { SDt } \\
6,71\end{array}$} \\
\hline $\begin{array}{l}\text { Kelas } \\
\text { Eksperi }\end{array}$ & $\begin{array}{l}\text { Pre } \\
\text { test }\end{array}$ & & & & \\
\hline & $\begin{array}{l}\text { Pos } \\
\text { test }\end{array}$ & 85,2 & 95,8 & 79,2 & 5,45 \\
\hline $\begin{array}{l}\text { Kelas } \\
\text { Kontrol }\end{array}$ & $\begin{array}{l}\text { Pre } \\
\text { test }\end{array}$ & 27 & 50 & 4,2 & 12,4 \\
\hline \multirow{3}{*}{$\begin{array}{l}\% \\
\text { Kenaikan }\end{array}$} & $\begin{array}{l}\text { Pos } \\
\text { test }\end{array}$ & 78,8 & 95,8 & 58,3 & 9,31 \\
\hline & EK & \multicolumn{4}{|c|}{$170 \%$} \\
\hline & $\mathrm{KO}$ & \multicolumn{4}{|c|}{$190 \%$} \\
\hline
\end{tabular}

Berdasarkan hasil perhitungan dengan menggunakan program SPSS untuk mengetahui homogenitas diketahui bahwa $\mathrm{P}$ (sig. Pre test dan Post test eksperimen dan kontrol pada tabel $6>$ sig. $(0,05)$ artinya data yang diperoleh memiliki varians yang sama atau homogen. Pada pre test di kelas eksperimen dan kontrol memiliki taraf signifikansi $0,948>$ signifikansi 0,05 dan pada post test kelas eksperimen dan kontrol memiliki taraf signifikasi $0,823>$ signifikansi 0,05 .

Table 7. Hasil Rerata Perbitungan Gain Skor

\begin{tabular}{cc}
\hline \multicolumn{2}{c}{ Rata-rata N-Gain Score } \\
\hline Kelas Eksperimen & Kelas Kontrol \\
\hline 0,79 & 0,71 \\
Persentase $(79 \%)$ & Persentase $(71 \%)$ \\
\hline
\end{tabular}


Berdasarkan hasil perhitungan Tabel 7 diketahui nilai rata-rata gain score pada kelas eksperimen yaitu 0,79 (persentase 79\%) lebih besar dibanding kelas kontrol yaitu 0,71 (persentase 71\%). Dengan demikian kelas eksperimen dan kontrol termasuk dalam kategori sangat baik

Table 8. Nilai Rata-rata Indeks Sensitifitas Kelas Eksperimen dan Kontrol

\section{Indeks Sensitifitas}

\begin{tabular}{cc}
\hline Kelas Eksperimen & Kelas Kontrol \\
\hline 0,67 & 0,61 \\
\hline
\end{tabular}

Uji Prasyarat

i. Uji Normalitas

Uji normalitas dilakukan setelah data diperoleh dari penelitian. Tujuannya untuk mengetahui apakah data yang diperoleh merupakan data yang berdistribusi normal atau tidak. dapat dilihat pada tabel 8 .

Table 9 Hasil Uji Normalitas

\begin{tabular}{lllll}
\hline & \multirow{2}{*}{ Perlakuan } & \multicolumn{3}{c}{ Kolmogorof-Smirnov } \\
\cline { 3 - 5 } & Sig. & (p) Sig & $\begin{array}{l}\text { Ketera } \\
\text { ngan }\end{array}$ \\
\hline $\boldsymbol{P r}$ & eksperime &, 036 & $\mathrm{P}>$ & Tidak \\
$\boldsymbol{e} \boldsymbol{t}$ & $\mathrm{n}$ & & 0,05 & normal \\
\cline { 3 - 5 } $\boldsymbol{e s}$ & kontrol &, 009 & $\mathrm{P}>$ & Tidak \\
$\boldsymbol{t}$ & & & 0,05 & normal \\
\hline $\boldsymbol{P}$ & eksperime &, 000 & $\mathrm{P}>$ & Tidak \\
$\boldsymbol{o s}$ & $\mathrm{n}$ & & 0,05 & normal \\
\cline { 2 - 5 } $\boldsymbol{t e}$ & kontrol &, 002 & $\mathrm{P}>$ & Tidak \\
$\boldsymbol{s t}$ & & & 0,05 & normal \\
\hline
\end{tabular}

Berdasarkan hasil uji pada Tabel 8 diketahui data tidak berdistribusi normal, dari hasil perhitungan dilihat signifikansi yang diperoleh pada tabel diketahui kurang dari signifikansi yang ditetapkan yaitu kurang dari 0,05.

ii. Uji Homogenitas

Uji ini dilakukan untuk mengetahui apakah data memiliki variansi yang sama atau tidak. Dapat dilihat pada Tabel 9.
Table 10. Hasil Uji Homogenitas

\begin{tabular}{|c|c|}
\hline & $\begin{array}{l}\text { Levene df1 df2 Sig. Keterangan } \\
\text { Statisti } \\
\quad c\end{array}$ \\
\hline $\begin{array}{l}\text { Pretes } \\
\mathrm{t}\end{array}$ & $\begin{array}{lllll}, 004 & 1 & 66 & , 948 & \text { Homogen }\end{array}$ \\
\hline $\begin{array}{l}\text { Postes } \\
\text { t }\end{array}$ & $\begin{array}{llll} & 66 & , 823 & \text { Homogen }\end{array}$ \\
\hline $\begin{array}{l}\text { B } \\
\text { mengguna } \\
\text { homogeni } \\
\text { Post test ek } \\
(0,05) \text { artir } \\
\text { yang sama } \\
\text { eksperime } \\
0,948>\text { s } \\
\text { eksperime } \\
0823>\text { si }\end{array}$ & $\begin{array}{l}\text { lasarkan hasil perhitungan dengan } \\
\text { n program SPSS untuk mengetahui } \\
\text { diketahui bahwa P (sig. Pre test dan } \\
\text { erimen dan kontrol pada tabel } 6>\text { sig. } \\
\text { data yang diperoleh memiliki varians } \\
\text { tau homogen. Pada pre test di kelas } \\
\text { dan kontrol memiliki taraf signifikansi } \\
\text { hifikansi } 0,05 \text { dan pada post test kelas } \\
\text { dan kontrol memiliki taraf signifikasi }\end{array}$ \\
\hline
\end{tabular}

iii. Uji Hipotesis

Berdasarkan hasil uji prasyarat diketahui bahwa data pre test dan post test tidak berdistribusi normal dan data bersifat homogen (tidak memenuhi syarat analisis keparametrikan). Hal ini memutuskan peneliti untuk melanjutkan uji hipotesis menggunakan syarat non parametrik karena tidak terpenuhi syarat analisis parametrik.

Uji yang digunakan adalah Mann Withney $U$-Test yang bertujuan untuk mengetahui efektifitas penggunaan modul biologi PBL dan adakah perbedeaan antara kelas eksperimen yang menggunakan modul biologi PBL dengan kelas kontrol yang tidak menggunakan modul biologi PBL tetapi hanya menggunakan model PBL dalam meningkatkan kemampuan berpikir kritis peserta didik, untuk lebih jelas dapat dilihat pada Tabel 10.

Table 11. Hasil Mann Withney U-Test

\begin{tabular}{ccc}
\hline & PretesEK & $\begin{array}{c}\text { PostetsE } \\
\text { K }\end{array}$ \\
\hline $\begin{array}{c}\text { Mann-Whitney } \\
\text { U }\end{array}$ & 422,000 & 319,000 \\
\hline Wilcoxon W & 1017,000 & 914,000 \\
\hline Z & $-1,930$ & $-3,288$ \\
\hline $\begin{array}{c}\text { Asymp. Sig. (2- } \\
\text { tailed) }\end{array}$ &, 054 &, 001 \\
\hline
\end{tabular}


Berdasarkan Tabel 10 dapat diketahui bahwa hasil pre test antara kelas kontrol dan eksperimen tidak memiliki perbedaan yang bermakna antara dua kelompok karena belum diberikan perlakuan pada kelas eksperimen dan kontrol, terlihat dari nilai U sebesar 422 dan nilai W sebesar 1017. Jika dikonversi ke nilai Z maka besarnya -1,930. Nilai signifikansi atau $P$ value sebesar $0,054>0,05$, jadi nilai $p$ value $>$ batas kiri 0,05 maka disimpulkan $\mathrm{H} 1$ ditolak dan Ho diterima.

Hasil analisis deskriptif dan uji hipotesis dapat diketahui bahwa kelas eksperimen yang diberikan perlakuan menggunakan modul biologi yang diadaptasi menggunakan model PBL lebih unggul dibanding dengan kelas kontrol yang menggunakan buku dan LKS dari sekolah serta model PBL tanpa modul PBL. Hal ini dikarenakan modul memiliki beberapa keunggulan dibanding pembelajaran yang dilakukan oleh guru secara langsung yaitu sebagai bahan ajar yang pelengkap yang di dalamnya terdapat ilustrasi dan foto yang lebih komunikatif (Andi Prastowo, 2014, p.212). Kemudian modul dapat dibuat secara mandiri oleh guru dan disesuaikan dengan materi yang memang cocok untuk menggunakan modul. Diketahui dari hasil rerata skor, peserta didik yang menggunakan modul biologi PBL lebih efektif dalam mengembangkan kemampuan berpikir kritis dibanding kelas kontrol, karena didalam modul yang dikembangkan peserta didik dapat belajar secara mandiri dan sesuai dengan petunjuk pengerjaan yang dilampirkan sehingga peserta didik dapat fokus mengerjakan sesuai dengan urutan sintaks PBL dalam modul serta dapat lebih mengembangkan kemampuan berpikir terutama berpikir kritis dalam memcahkan permasalahan untuk mengambil suatu keputusan.

Pada kelas kontrol yang tidak menggunakan modul biologi PBL hanya menggunakan model PBL pembelajaran dipimpin secara langsung oleh guru sesuai dengan sintaks dan dari hasil pengamatan peserta didik kurang mengeksplor kemampuan yang dimiliki dalam belajar secara kooperatif maupun mandiri, sehingga modul biologi PBL yang dikembangkan sesuai dengan pernyataan dari Parmin (2012, p.8) bahwa modul merupakan komponen yang memiliki peran penting dalam proses pembelajaran karena ketersediaan modul dapat membantu memperoleh informasi tentang materi pelajaran.

\section{SIMPULAN DAN SARAN Simpulan}

Berdasarkan hasil penelitian dan pengembangan yang telah dilakukan di lapangan maka dapat disimpulkan dalam beberapa hal yaitu:
(1) Berdasarkan hasil validasi yang dilakukan oleh face validity menggunakan desain 4-D diketahui bahwa modul dapat layak untuk digunakan karena telah memenuhi syarat penilaian aspek substansi, aspek konstruksi dan aspek bahasa (komunikasi), (2) modul biologi problem based learning efektif dalam meningkatkan kemampuan berpikir kritis peserta didik dapat dilihat dan (3) terdapat perbedaan hasil belajar antara kelas eksperimen dan kontrol dilihat belajar peserta didik yang menggunakan modul dengan langkah PBL secara mandiri lebih tinggi dibanding dengan yang dibimbing oleh guru tanpa modul.

Saran

Adapun saran untuk pengembangan produk selanjutnya yaitu: (1) produk yang dikembangkan hanya sampai pada tahap validasi yaitu tahap develop (pengembangan), agar produk dapat diterapkan pada skala luas maka perlu dilakukan penelitian lebih lanjut sampai pada tahap disseminate (penyebarluasan), (2) modul biologi problem based learning (PBL) dapat dikembangkan kembali oleh guru bidang studi sebagai salah satu media pembelajaran, tidak hanya pada materi sistem pernapasan tetapi pada materi lain yang sesuai dengan model yang digunakan, (3) modul biologi ini dapat divariasi pembuatannya dengan menggunakan model pembelajaran lain dengan langkah-langkah yang sesuai untuk diadaptasi dalam modul, dan (4) modul biologi problem based learning (PBL) juga dapat mengukur kemampuan berpikir lain yang disesuaikan dengan model pembelajaran yang diadaptasi bersama modul, seperti kemampuan pemecahan masalah, kemampuan berpikir kreatif dan lainnya.

\section{DAFTAR PUSTAKA}

Arends, R., I. (2012). Learning to teach. New York: The McGraw-Hill Companies, Inc.

Baden, M., S. (2000). Problem based learning in Higher Education: Untold Stories. Philadelphia: SHRE and Open University Press.

Daryanto. (2013). Menyusun modul (bahan ajar untuk persiapan guru dalam mengajar. Yogyakarta: Gava Media.

Depdiknas, Direktorat jendral manajemen pendidikan dasar dan menengah, direktorat pembinaan sekolah menengah atas. (2008). Panduan Pengembangan Bahan Ajar. 
Facione, P., A. (2011). Measure reasons critical thinking: what it is and why it counts (rev. ed.). Millbrae, CA: Insight Assessment.

Fischer, A. (2001). A critical thinking in a introductional. Cambridge: Syndicate of the University of Cambridge.

Hudgins, B., B. (1983). Educational psycology, Illinois: F.E Peacick Publishers, Inc.

Levin, B., B. (2001). Energizing teacher education and professional development with problem based learning. Virginia: Association for Supervision and Curriculum Development.

Maknun, D., Surtikanti, R. R. H. K., \& Subahar, T. S. (2012).

PEMETAAN KETERAMPILAN ESENSIAL LABORATORIUM DALAM KEGIATAN PRAKTIKUM EKOLOGI. Jurnal Pendidikan IPA Indonesia, 1(1). https://doi.org/10.15294/jpii.v1i1.2003

Pangastuty, A. G., Cahyana, U., \& Purwanto, A. (2017). PENGEMBANGAN MEDIA LECTUREMAKER DALAM PEMBELAJARAN KIMIA SMA POKOK BAHASAN IKATAN KIMIA MELALUI PENERAPAN PROFESSIONAL LEARNING COMMUNITY. JRPK: Jurnal Riset Pendidikan Kimia. https:/ /doi.org/10.21009/jrpk.031.04

Parmin., \& Peniati, E. (2012). Pengembangan modul mata kuliah strategi belajar mengajar ipa berbasis hasil penelitian pembelajaran. Jurnal Pendidikan IPA Indonesia, Semarang, 1(1), 8-15.

Poppy, Sofiraeni, \& Khaeruddin. (2009). Pengembangan perangkat pembelajaran untuk. guru SMP. Bandung: Pusat Pengembangan dan Pemberdayaan Pendidik dan Tenaga Pendidik Ilmu Pengetahuan Alam (PPPPTK IPA).

Prasetyaningtyas, F. D. (2019). Inovasi Model Quantum Learning Menggunakan Teori Apersepsi Berbasis Karakter untuk Meningkatkan Kualitas Pembelajaran Matakuliah Pendidikan IPS SD. ELSE (Elementary School Education Journal): Jurnal Pendidikan Dan Pembelajaran Sekolah Dasar,
3(2)

https://doi.org/10.30651/else.v3i2.2682

Prastowo, Andi. (2014). Pengembangan bahan ajar tematik tinjauan teoritis dan praktik. Jakarta: Kencana Prenadamedia Group.

Ricketts, J., C., \& Rudd, R., D. (2005). Critical thinking skills of selected youth leaders: the efficacy of critical thinking dispositions, leadership, and academic performance. Journal of Agricultural Education,Morgantown, 46 (1), 32-43.

Rizkiana, F., Dasna, I. W., \& Marfu'ah, S. (2016). PENGARUH PRAKTIKUM DAN

DEMONSTRASI DALAM

PEMBELAJARAN INKUIRI

TERBIMBING TERHADAP

MOTIVASI BELAJAR SISWA PADA MATERI ASAM BASA DITINJAU DARI KEMAMPUAN AWAL. Jurnal Pendidikan: Teori, Penelitian, Dan Pengembangan, 1(3), 354-362. https://doi.org/10.17977/JP.V1I3.6161

Savery, J., R. (2006). Overview of problem-based learning: definitions and distinctions. The Interdisciplinary Journal of Problem-based Learning, West Lafayette, Indiana, US A, 1 (1), 9-20.

Schafersman, S., D. (1991). An introduction to critical thinking. Diambil Tanggal: 9 September 2015, dari http://facultycenter.ischool.syr.edu/wpcontent/uploads/2012/02/Criticalthinking.pdf

Seels, B.B., \& Richey, R.C. (1994). Instructional technology: the definition and domains of the field. Dalam Richey, Rita, C., \& Klein, James D. 2005. Developmental Research Methods: Creating Knowledge from Instructional Design and Development Practice. (pp. 23-38) Journal of Computing in Higher Education.

Sinprakob, S., \& Noawanit Songkram. (2014). A proposed model of problem-based learning on social media in cooperation with searching technique to enhance critical thinking of undergraduate student. Proceeding and Conference INTE 2014, London, 174, 2027-2030.

Sirisopon, N., \& Saroch Sopeerak. (2013). Web- 
based instruction model under constructionism for critical thinking development. Proceeding 13th International Educational Technology Conference, London, 103,1309-1318.

Subali, B. (2012). Prinsip asessmen dan evaluasi pembelajaran. Yogyakarta: UNY Press.

Supriyatno, N. (2006). Pengembangan modul diktat dan pengembangan diklat. Jakarta.

Suryosubroto, B. (1983). Sistem pengajaran dengan modul. Jakarta: Bina aksara.

Thiagarajan, S., Dorothi S. Semmel., \& Melvyn I. Semmel. (1974). Instructional development for training teacher of exceptional chidren:a source. Blommington: Indiana University

Vembriarto, ST. (1975). Pengantar pengajaran modul. Yogyakarta: Yayasan Pendidikan Paramita.

Widiyaningtyas, T., \& Widiatmoko, A. (2014). Media Pembelajaran Berbasis Web Pada Mata Pelajaran Kimia. Jurnal Teknologi, 21, 47-51.

Wijaya, C. (1992). Upaya pembaharuan dalam pendidikan dan pengajaran. Bandung: Remaja Rosda Karya.

Yarid, H., \& Ariswan, A. (2016). Pengembangan perangkat pembelajaran fisika problem based learning melalui kegiatan fieldtrip pada materi energi. Jurnal Inovasi Pendidikan IP A, 2(1), 24-34. 